\title{
SCREENING OF TOMATO VARIETIES AGAINST TOMATO FRUIT BORER AND ASSOCIATED PLANT CHARACTERS
}

\author{
M. R. Amin ${ }^{1 *}$, A. Chakma ${ }^{1}$, M. Z. Alam ${ }^{1}$, M. M. Hossain ${ }^{2}$ and F. Ge \\ ${ }^{1}$ Department of Entomology, Bangabandhu Sheikh Mujibur Rahman Agricultural University, \\ Gazipur 1706, Bangladesh \\ ${ }^{2}$ Department of Horticulture, Bangabandhu Sheikh Mujibur Rahman Agricultural University, \\ Gazipur 1706, Bangladesh \\ ${ }^{3}$ State Key Laboratory of Integrated Pest Management of Insect Pests and Rodents, Institute \\ of Zoology, Chinese Academy of Sciences, Beijing, China
}

\begin{abstract}
Ten tomato varieties were evaluated to find out their level of resistance against tomato fruit borer Helicoverpa armigera Hubner (Lepidoptera: Noctuidae) under field conditions. The abundance of fruit borer larvae and their infestation, plant morphological characters, nitrogen content, yield and seed germination of the varieties were studied. The varieties differed in their leaf thickness, trichome density, rind thickness and nitrogen content. The fruit borer larval abundance and fruit infestation among the varieties varied significantly. Five varieties namely BARI Tomato-1, BARI Tomato-4, BARI Tomato-10, BARI Tomato-11 and BARI Tomato-15 were least infested by fruit borer (3.6 to 10.0\%) and had significantly lower abundance of larvae (0.3 to 0.7 plant $\left.^{-1}\right)$, and the varieties were classified as resistant. The yield reduction and seed germination of these varieties ranged from 3.9 to $7.9 \%$ and 76.7 to $90.7 \%$, respectively. Four varieties namely BARI Tomato-2, BARI Tomato-5, BARI Tomato-12 and BARI Tomato-14 were graded as moderately resistant as the varieties showed 12.4 to $16.2 \%$ fruit infestation and revealed 1.0 to 1.3 larvae plant ${ }^{-1}$. The yield reduction and seed germination of these varieties ranged from 9.6 to $13.2 \%$ and 66.7 to $73.3 \%$, respectively. Only the variety BARI Tomato-7 was categorized as moderately susceptible which had significantly the highest abundance of fruit borer larva (1.7plant $\left.{ }^{-1}\right)$, fruit infestation $(22.2 \%)$ and yield loss $(15.9 \%)$, and lowest germination performance $(62.7 \%)$. The study indicated that the varieties differed in their levels of resistance and this promising source of resistance may be incorporated in the integrated management of tomato fruit borer.
\end{abstract}

\footnotetext{
* Corresponding author email: mramin.bsmrau@yahoo.com
} 
Keywords: Fruit borer, Helicoverpa armigera, Lycopersicon esculentum, trichome

\section{INTRODUCTION}

Tomato Lycopersicon esculentum Mill is a major winter vegetable of Bangladesh. One of the major constraints of tomato production in Bangladesh is infestation of insect pests. The crop is devastated by the insect fruit borer Helicoverpa armigera Hubner (Lepidoptera: Noctuidae) which is noted as polyphagous pest and caused damage to 181 cultivated and uncultivated plant species distributed in 45 families (Matthews, 1999). The H. armigera larvae damage tomato plants by feeding on buds, flowers and fruits. The newly hatched larvae bore into the fruit and feed inside. As a result, the fruits become unfit for human consumption. They are responsible for lowering the yield of tomato (Bhatt and Patel, 2001; Mehrvar, 2009). It was reported that infestation level of $H$. armigera on tomato was up to $46.8 \%$ in Bangladesh (Alam et al., 2007) and 35\% in India (Dhandapani et al., 2003).

Proper variety selection and protection of tomato fruits from the attack of fruit borer is an important prerequisite for higher yield and quality of the crop. Management of fruit borer through insecticides is hazardous to human being and insecticides reduce insect predator and pollinator species in the field (Moser and Obrycki, 2009). Plant morphological characteristics such as trichomes and thickness of the cuticle affect $H$. armigera larval movement and feeding rate (Shelomi et al., 2010; Amin et al., 2015). The biochemical contents and nutrients in the host plant affect survival, growth and reproduction of phytophagous insects (Browne and Raubenheimer, 2003). Thus the morphological traits and biochemical contents of the plants have important roles in varietal resistance.

Cultivation of resistant variety is economical and safer, and it is the most important tool in integrated pest management (IPM). Reduction in pest infestation to an acceptable level with the use of resistant variety alone or in combination with other control measures has been reported. However, there has been lack of information regarding resistance in commercially available tomato varieties. The present study was undertaken with ten varieties of tomato which were developed by the Bangladesh Agricultural Research Institute (BARI) to find out their level of resistance against $H$. armigera in the field conditions. The plant morphological characteristics associated with resistance, nitrogen content in the plant, and performances of yield and seed germination of the varieties were also assessed.

\section{MATERIALS AND METHODS}

The study was carried out in the experimental field of the Department of Entomology, Bangabandhu Sheikh Mujibur Rahman Agricultural University (BSMRAU), Gazipur, Bangladesh during November 2015 to June 2016. The seeds of 
the tomato varieties namely BARI Tomato-1, BARI Tomato-2, BARI Tomato-4, BARI Tomato-5, BARI Tomato-7, BARI Tomato-10, BARI Tomato-11, BARI Tomato-12, BARI Tomato-14 and BARI Tomato-15 were collected from the (BARI), Gazipur.

\section{Cultivation of the tomato varieties}

Seeds of the tomato varieties were sown separately in a well prepared seed bed (size $3 \times 0.6 \mathrm{~m}$ and $15 \mathrm{~cm}$ in height) to raise seedling. The distance between two beds was $70 \mathrm{~cm}$. Seeds were sown on $31^{\text {st }}$ October and the seed rate was $300 \mathrm{~g} \mathrm{ha}^{-1}$. Prior to sowing seeds were treated with Thiram $\left(2 \mathrm{~g} \mathrm{~kg}^{-1}\right.$ of seed) to avoid damage from damping off disease. Seeds were sown at a depth of $2-3 \mathrm{~cm}$ and covered with a fine layer of soil followed by light watering by water can. The beds were covered with dry straw to maintain temperature and moisture. The cover of dry straw was removed immediately after germination had complete. During the last week in nursery, the seedlings were hardened by slightly withholding water. The seedlings were cultivated in a completely randomized design with a plot size of $3.0 \times 2.0 \mathrm{~m}$. Each variety was cultivated in three plots and there were 30 plots in this experiment. The spacing among the plots was $1.0 \mathrm{~m}$. Seeds were sown on 20 November 2015 in rows. Each plot contained three rows and each row had 5 seedlings. The distance between two seedlings was $60 \mathrm{~cm}$. The plants were supported by bamboo sticks to prevent lodging. The applied doses of NPK fertilizers for this study were $550 \mathrm{~kg}$ urea, $450 \mathrm{~kg}$ TSP, $250 \mathrm{~kg} \mathrm{MoP} \mathrm{ha}^{-1}$, respectively. The entire quantity of TSP and 1/3 MoP were applied during final land preparation. The entire urea and the rest of MoP were applied in three equal installments at 15, 30 and 50 days after transplanting. Intercultural operations such as mulching, weeding, irrigation etc were done whenever necessary. No plant protection measure was applied in the field.

\section{Screening against fruit borer}

The study field was monitored weekly to observe the abundance of fruit borer larvae and fruit infestation by them. To count the number of fruit borer larvae plant ${ }^{-1}$, third plant in each row was selected for each variety at 30,50 and 70 days after transplanting. The total number of healthy fruits and infested fruits of each variety were recorded at each harvesting stage. Fruits were categorized as healthy and infested based on the absence or presence of pod borer infestation. The damaged and undamaged fruits were harvested five times and percentage of fruit infestation was calculated on number basis. A rating system for fruit damage developed by Kashyap and Verma (1986) was followed for estimating relative resistance/susceptibility.

\section{Determination of $\mathbf{N}_{2}$ in the fruit}

Percentage of nitrogen in healthy fruits of each variety was determined using the conventional Kjeldahl method. Chopped, oven dried, healthy fruit of each variety $(1.0 \mathrm{~g})$ was weighed using a digital balance (MR 220 no. 971373; Mettler, Berlin, Germany) and transferred to Kjeldahl flasks. For each sample, concentrated $\mathrm{H}_{2} \mathrm{SO}_{4}$ 
$(20 \mathrm{ml})$ was added in the presence of $3-4 \mathrm{~g}$ catalyst mixture $\left(\mathrm{K}_{2} \mathrm{SO}_{4}-\mathrm{CuSO}_{4}, 5: 1\right)$. The flask was continuously heated until the solution became clear. The flask was then allowed to cool and $150 \mathrm{ml}$ distilled water was added. A few zinc granules were added to the mixture. One hundred milliliters of $40 \% \mathrm{NaOH}$ was then poured into the flask, which was immediately attached to a distillation set. An Erlenmeyer flask containing methyl red and methyl blue indicator was placed underneath prior to collecting the distillate. Approximately $150 \mathrm{ml}$ of distillate was collected and titrated with standardized $0.1 \mathrm{~N} \mathrm{HCl}$. The nitrogen content was calculated using the equation:

$$
\% \mathrm{~N}=\frac{(\mathrm{T}-\mathrm{B}) \times \mathrm{N} \times 1.4}{\mathrm{~s}} \times 100
$$

Where, $\mathrm{T}$ is the sample titer $(\mathrm{ml}), \mathrm{B}$ is the blank titer $(\mathrm{ml}), \mathrm{N}$ is the concentration of $\mathrm{HCl}(0.1 \mathrm{~N})$ and $\mathrm{S}$ is sample weight.

\section{Identification of plant morphological characters and calculation of yield}

Leaf thickness and number of trichomes were observed on the terminal leaflet of the fourth leaf in 3 plants per variety. From each leaflet $1 \mathrm{~cm}^{2}$ section was taken from $1.5 \mathrm{~cm}$ above the base and $0.5 \mathrm{~cm}$ from each side of the main vein. Rind thickness was measured on the physiological mature fruits. Three fruits were randomly selected for each variety and from each fruit $1 \mathrm{~cm}^{2}$ section, located at 0.5 $\mathrm{cm}$ from the calyx was taken. Leaf thickness and rind thickness were measured with an ocular micrometer (Carl Zeiss, Germany) at 10X amplification under a microscope (Carl Zeiss, Germany). Number of leaf trichomes was counted under the microscope. At each harvesting stage, data on fruit length, diameter and weight were taken from the healthy and infested fruits. Fruit length and diameter was measured with slide calliper and weight was taken with a digital balance (AG204, Mettler Toledo, Switzerland). The fruit yield recorded in each harvesting stage of a variety was pooled for the entire season and calculated in tons per hectare.

\section{Germination test}

The percentage of seed germinated indicates the seed quality of the varieties. A germination test was conducted in homogenous environmental conditions in the laboratory at $25{ }^{\circ} \mathrm{C}$. Trays $(30 \mathrm{~cm} \times 30 \mathrm{~cm} \times 5 \mathrm{~cm})$ were used for this purpose. A single sheet of paper was placed in the bottom of each tray to cover drainage holes. The trays were filled with clean, moist sand, and fresh sand was used for each test.

Seeds of each variety were randomly collected from their respective bags and counted. For each variety, 100 seeds were sown on each of five replicate trays in 4 rows of 25 seeds. Seeds were sown at the normal seeding depth of 2-3 cm and watered every second day. Only normal seedlings were counted after 10 days when the majority of seedlings had emerged. Diseased, discolored, or malformed seedlings were excluded from counts. The total number of normal, vigorous, and healthy seedlings for each variety was used to determine germination percentage. Normal seedlings, abnormal seedlings, and non-germinated seeds were defined and detected according to the International Seed Testing Association (ISTA) protocol. 


\section{Statistical analysis}

Data were analyzed by one way analysis of variance (ANOVA) and the mean values were separated by Duncan multiple range test (DMRT). All the analyses were performed using SPSS (IBM Statistics 21.0).

\section{RESULTS}

Table 1 showed that the leaf thickness, number of trichomes, rind thickness and nitrogen content of the varieties differed significantly (leaf thickness: $F_{9,20}=44.9, p$ $<0.001$; number of trichomes: $\mathrm{F}_{9,20}=11.8, \mathrm{p}<0.001$; rind thickness: $\mathrm{F}_{9,20}=18.5, \mathrm{p}$ $<0.001$ ); nitrogen content: $\left.\mathrm{F}_{9,20}=51.9, \mathrm{p}<0.001\right)$. The BARI Tomato-10 revealed the highest leaf thickness and the varieties BARI Tomato-2 and BARI Tomato-12 showed statistically similar and lowest leaf thickness. The BARI Tomato-15 and BARI Tomato-10 revealed statistically identical and higher number of trichomes and the varieties BARI Tomato-7 and BARI Tomato-5 showed statistically similar and lower number of trichomes. The BARI Tomato-12 had highest rind thickness followed by BARI Tomato-4. Other varieties revealed statistically similar and lower rind thickness. Nitrogen content was found statistically similar and higher in BARI Tomato-7, BARI Tomato-11 and BARI Tomato-12, and that was lowest in BARI Tomato-1.

Table 1. Variations in leaf thickness $(\mathrm{mm})$, trichomes (number per $\mathrm{cm}^{2}$ ), rind thickness $(\mathrm{mm})$ and nitrogen content $(\%)$ among the tomato varieties

\begin{tabular}{lllll}
\hline Variety & Leaf thickness & Trichomes & Rind thickness & Nitrogen \\
\hline BARI Tomato -1 & $0.82 \pm 0.01 \mathrm{ef}$ & $4.7 \pm 0.3 \mathrm{~b}$ & $0.51 \pm 0.02 \mathrm{c}$ & $2.2 \pm 0.03 \mathrm{~d}$ \\
BARI Tomato -2 & $0.74 \pm 0.02 \mathrm{~g}$ & $4.0 \pm 0.0 \mathrm{bc}$ & $0.35 \pm 0.03 \mathrm{~d}$ & $2.5 \pm 0.07 \mathrm{c}$ \\
BARI Tomato -4 & $1.0 \pm 0.01 \mathrm{c}$ & $3.7 \pm 0.3 \mathrm{bd}$ & $0.73 \pm 0.02 \mathrm{~b}$ & $2.8 \pm 0.03 \mathrm{ab}$ \\
BARI Tomato -5 & $1.0 \pm 0.03 \mathrm{~b}$ & $2.7 \pm 0.3 \mathrm{~d}$ & $0.55 \pm 0.03 \mathrm{c}$ & $2.3 \pm 0.03 \mathrm{~d}$ \\
BARI Tomato -7 & $0.76 \pm 0.01 \mathrm{fg}$ & $2.7 \pm 0.3 \mathrm{~d}$ & $0.37 \pm 0.02 \mathrm{c}$ & $2.8 \pm 0.05 \mathrm{a}$ \\
BARI Tomato -10 & $1.18 \pm 0.04 \mathrm{a}$ & $5.7 \pm 0.3 \mathrm{a}$ & $0.48 \pm 0.04 \mathrm{c}$ & $2.2 \pm 0.02 \mathrm{~d}$ \\
BARI Tomato -11 & $0.9 \pm 0.01 \mathrm{~d}$ & $3.3 \pm 0.3 \mathrm{~cd}$ & $0.55 \pm 0.05 \mathrm{c}$ & $2.9 \pm 0.05 \mathrm{a}$ \\
BARI Tomato -12 & $0.74 \pm 0.02 \mathrm{~g}$ & $3.3 \pm 0.3 \mathrm{~cd}$ & $0.84 \pm 0.03 \mathrm{a}$ & $2.9 \pm 0.01 \mathrm{a}$ \\
BARI Tomato -14 & $0.75 \pm 0.00 \mathrm{fg}$ & $3.7 \pm 0.3 \mathrm{bd}$ & $0.45 \pm 0.05 \mathrm{~cd}$ & $2.2 \pm 0.04 \mathrm{~d}$ \\
BARI Tomato -15 & $0.86 \pm 0.02 \mathrm{de}$ & $5.7 \pm 0.3 \mathrm{a}$ & $0.57 \pm 0.03 \mathrm{c}$ & $2.7 \pm 0.05 \mathrm{bc}$ \\
\hline
\end{tabular}

Data expressed as mean \pm SE. Means within a column followed by same letter(s) are not significantly different by DMRT $(\mathrm{p} \leq 0.05)$. 
Table 2 indicated that the screened varieties were infested by $H$. armigera but their level of infestation differed significantly $\left(F_{9,20}=9.1, p<0.001\right)$. None of the varieties was found highly resistant to the fruit borer. The BARI Tomato-11, BARI Tomato-10, BARI Tomato-15, BARI Tomato-4 and BARI Tomato-1 revealed lower level of fruit infestation and these varieties were classified as resistant. The BARI Tomato-5, BARI Tomato-2, BARI Tomato-12 and BARI Tomato-14 showed medium level of infestation and these varieties were classified as moderately resistant. The BARI Tomato-7 showed highest level of infestation and this variety was classified as moderately susceptible. The fruit borer larval population on the screened varieties ranged from $0.3 \pm 0.3$ to $1.7 \pm 0.3$ plant $^{-1}$, and the results differed significantly $\left(\mathrm{F}_{9,20}=2.6, \mathrm{p}<0.05\right.$; Table 2$)$. The BARI Tomato-7 showed the highest number of fruit borer larval population while BARI Tomato-2, BARI Tomato-5, BARI Tomato-12 and BARI Tomato-14 showed intermediate response. The BARI Tomato-1, BARI Tomato-4, BARI Tomato-10, BARI Tomato-11 and BARI Tomato-15 revealed statistically similar and lower number of larval population. These five varieties were classified as resistant to tomato fruit borer on the basis of fruit infestation. There were found significant differences in the lengths of healthy and infested fruits (healthy fruit length: $\mathrm{F}_{9,20}=52.7, \mathrm{p}<0.001$; infested fruit length: $\mathrm{F}_{9,20}=46.5, \mathrm{p}<0.001$; Table 3). The BARI Tomato-7 and BARI Tomato-12 revealed statistically similar and longer fruits compared to other varieties. Fruit lengths of the studied varieties showed reduction due to the infestation of fruit borer. The BARI Tomato-11 and Tomato-4 revealed the highest and lowest length reduction, respectively.

Table 2. Responses of different tomato varieties to fruit borer larval population abundance and fruit infestation

\begin{tabular}{llll}
\hline Variety & Number of larvae plant & \% Fruit infestation & Resistant category \\
\hline BARI Tomato -1 & $0.3 \pm 0.3 \mathrm{~b}$ & $10.0 \pm 1.7 \mathrm{c}$ & Resistant \\
BARI Tomato -2 & $1.0 \pm 0.0 \mathrm{ab}$ & $12.6 \pm 3.4 \mathrm{bc}$ & Moderately resistant \\
BARI Tomato -4 & $0.7 \pm 0.3 \mathrm{~b}$ & $9.5 \pm 1.2 \mathrm{c}$ & Resistant \\
BARI Tomato -5 & $1.0 \pm 0.0 \mathrm{ab}$ & $12.4 \pm 0.5 \mathrm{bc}$ & Moderately resistant \\
BARI Tomato -7 & $1.7 \pm 0.3 \mathrm{a}$ & $22.2 \pm 2.9 \mathrm{a}$ & Moderately susceptible \\
BARI Tomato -10 & $0.3 \pm 0.3 \mathrm{~b}$ & $6.9 \pm 0.6 \mathrm{~cd}$ & Resistant \\
BARI Tomato -11 & $0.3 \pm 0.3 \mathrm{~b}$ & $3.6 \pm 0.5 \mathrm{~d}$ & Resistant \\
BARI Tomato -12 & $1.3 \pm 0.3 \mathrm{ab}$ & $15.7 \pm 1.6 \mathrm{~b}$ & Moderately resistant \\
BARI Tomato -14 & $1.3 \pm 0.3 \mathrm{ab}$ & $16.2 \pm 0.6 \mathrm{~b}$ & Moderately resistant \\
BARI Tomato -15 & $0.7 \pm 0.3 \mathrm{~b}$ & $7.3 \pm 1.8 \mathrm{~cd}$ & Resistant \\
\hline
\end{tabular}

Data expressed as mean \pm SE. Means within a column followed by same letter(s) are not significantly different by DMRT $(\mathrm{p} \leq 0.05)$. 
There were found significant differences in the diameters of the healthy $\left(\mathrm{F}_{9,20}=\right.$ $52.7, \mathrm{p}<0.001)$ and infested $\left(\mathrm{F}_{9,20}=42.8, \mathrm{p}<0.001\right)$ fruits of the screened varieties (Table 3). Both in healthy and infested fruits, the BARI Tomato-7 and BARI Tomato-11 revealed the highest and lowest diameter, respectively. The BARI Tomato-11 and BARI Tomato-15 revealed the highest and lowest diameter reduction, respectively. The weights of the healthy and infested fruits of the varieties differed significantly (healthy fruit weight: $\mathrm{F}_{9,20}=101.0, \mathrm{p}<0.001$; infested fruit weight: $\mathrm{F}_{9,20}$ $=19.8, \mathrm{p}<0.001$; Table 3). The BARI Tomato-7 showed the highest fruit weight both in healthy and infested conditions. The BARI Tomato-11 had the lowest fruit weight. The BARI Tomato-7 and BARI Tomato-1 showed the highest and lowest weight reduction, respectively.

Table 3. Effect of fruit borer infestation on the fruit length, diameter and weight of different tomato varieties

\begin{tabular}{|c|c|c|c|c|c|c|c|c|c|}
\hline \multirow[t]{2}{*}{ Variety } & \multicolumn{2}{|c|}{ Fruit length $(\mathrm{cm})$} & \multirow{2}{*}{$\begin{array}{l}\text { \%Length } \\
\text { reduction }\end{array}$} & \multicolumn{2}{|c|}{ Fruit diameter $(\mathrm{cm})$} & \multirow{2}{*}{$\begin{array}{l}\text { \% Diameter } \\
\text { reduction }\end{array}$} & \multicolumn{2}{|c|}{ Fruit weight (g) } & \multirow{2}{*}{$\begin{array}{l}\text { \% Weight } \\
\text { reduction }\end{array}$} \\
\hline & Healthy & Infested & & Healthy & Infested & & Healthy & Infested & \\
\hline BARI Tomato -1 & $6.3 \pm 0.07 \mathrm{bc}$ & $5.6 \pm 0.08 \mathrm{~b}$ & 10.0 & $6.6 \pm 0.07 \mathrm{c}$ & $5.2 \pm 0.20 \mathrm{~cd}$ & 21.7 & $74.5 \pm 1.2 \mathrm{bc}$ & $58.2 \pm 2.5 \mathrm{~b}$ & 21.9 \\
\hline BARI Tomato -2 & $6.0 \pm 0.10 \mathrm{bc}$ & $5.4 \pm 0.19 \mathrm{bc}$ & 10.5 & $6.4 \pm 0.16 \mathrm{c}$ & $5.6 \pm 0.16 \mathrm{c}$ & 14.2 & $70.9 \pm 3.1 \mathrm{~cd}$ & $49.1 \pm 1.4 \mathrm{bc}$ & 30.7 \\
\hline BARI Tomato -4 & $5.3 \pm 0.07 \mathrm{e}$ & $4.9 \pm 0.07 \mathrm{~d}$ & 7.3 & $6.0 \pm 0.11 \mathrm{~d}$ & $5.3 \pm 0.25 \mathrm{~cd}$ & 11.7 & $59.1 \pm 4.9 \mathrm{e}$ & $39.8 \pm 2.5 \mathrm{c}$ & 32.6 \\
\hline BARI Tomato -5 & $5.8 \pm 0.01 \mathrm{~cd}$ & $5.1 \pm 0.15 \mathrm{~cd}$ & 11.8 & $5.9 \pm 0.09 \mathrm{~d}$ & $5.4 \pm 0.09 \mathrm{c}$ & 9.5 & $54.9 \pm 0.93 \mathrm{e}$ & $38.9 \pm 3.3 \mathrm{c}$ & 29.1 \\
\hline BARI Tomato -7 & $7.3 \pm 0.17 \mathrm{a}$ & $6.1 \pm 0.11 \mathrm{a}$ & 17.7 & $8.3 \pm 0.13 \mathrm{a}$ & $6.8 \pm 0.24 \mathrm{a}$ & 17.3 & $116.5 \pm 2.3 \mathrm{a}$ & $70.1 \pm 3.9 \mathrm{a}$ & 39.8 \\
\hline BARI Tomato -10 & $4.4 \pm 0.23 \mathrm{f}$ & $3.9 \pm 0.15 \mathrm{e}$ & 10.5 & $4.8 \pm 0.14 \mathrm{f}$ & $4.1 \pm 0.20 \mathrm{e}$ & 12.7 & $38.2 \pm 1.4 \mathrm{f}$ & $27.7 \pm 2.6 \mathrm{~d}$ & 27.5 \\
\hline BARI Tomato -11 & $3.8 \pm 0.24 \mathrm{~g}$ & $3.0 \pm 0.11 \mathrm{f}$ & 19.8 & $3.6 \pm 0.30 \mathrm{~g}$ & $2.7 \pm 0.10 \mathrm{f}$ & 24.3 & $28.5 \pm 3.1 \mathrm{~g}$ & $20.3 \pm 2.8 \mathrm{~d}$ & 28.8 \\
\hline BARI Tomato -12 & $6.8 \pm 0.88 \mathrm{a}$ & $6.3 \pm 0.29 \mathrm{a}$ & 8.3 & $7.6 \pm 0.11 \mathrm{~b}$. & $6.1 \pm 0.17 \mathrm{~b}$ & 18.8 & $79.7 \pm 2.6 \mathrm{~b}$ & $55.8 \pm 3.5 \mathrm{~b}$ & 29.9 \\
\hline BARI Tomato -14 & $6.3 \pm 0.06 \mathrm{~b}$ & $5.8 \pm 0.12 \mathrm{ab}$ & 7.9 & $5.3 \pm 0.17 \mathrm{e}$ & $4.8 \pm 0.11 \mathrm{~d}$ & 9.9 & $77.6 \pm 1.5 \mathrm{bc}$ & $51.2 \pm 5.3 \mathrm{~b}$ & 34.0 \\
\hline BARI Tomato -15 & $5.5 \pm 0.15 \mathrm{de}$ & $5.0 \pm 0.06 \mathrm{~cd}$ & 8.9 & $5.9 \pm 0.13 \mathrm{~d}$ & $5.4 \pm 0.03 \mathrm{c}$ & 7.4 & $66.4 \pm 1.8 \mathrm{~d}$ & $47.6 \pm 3.4 \mathrm{bc}$ & 28.3 \\
\hline
\end{tabular}

Data expressed as mean \pm SE. Means within a column followed by same letter(s) are not significantly different by DMRT $(\mathrm{p} \leq 0.05)$. 
Table 4. Effect of fruit borer infestation on the yield and germination of different tomato varieties

\begin{tabular}{llllll}
\hline Variety & \multicolumn{2}{c}{ Yield of tomato fruit $\left(\mathrm{t} \mathrm{ha}^{-1}\right)$} & & Yield loss & Germination \\
& Total yield & Healthy fruit & Infested fruit & $(\%)$ & $(\%)$ \\
\hline BARI Tomato -1 & $37.4 \pm 3.7 \mathrm{a}$ & $34.4 \pm 3.4 \mathrm{a}$ & $2.9 \pm 0.7 \mathrm{bd}$ & 7.9 & $76.7 \pm 2.4 \mathrm{~b}$ \\
BARI Tomato -2 & $38.1 \pm 2.2 \mathrm{a}$ & $34.5 \pm 2.7 \mathrm{a}$ & $3.5 \pm 0.5 \mathrm{bc}$ & 9.6 & $73.3 \pm 1.3 \mathrm{bc}$ \\
BARI Tomato -4 & $39.0 \pm 3.3 \mathrm{a}$ & $36.2 \pm 3.4 \mathrm{a}$ & $2.8 \pm 0.3 \mathrm{ce}$ & 7.3 & $77.3 \pm 1.3 \mathrm{~b}$ \\
BARI Tomato -5 & $20.9 \pm 4.3 \mathrm{~b}$ & $18.5 \pm 4.1 \mathrm{bc}$ & $2.4 \pm 0.4 \mathrm{ce}$ & 10.8 & $66.7 \pm 1.8 \mathrm{de}$ \\
BARI Tomato -7 & $36.6 \pm 2.7 \mathrm{a}$ & $30.8 \pm 3.1 \mathrm{a}$ & $5.7 \pm 0.6 \mathrm{a}$ & 15.9 & $62.7 \pm 1.3 \mathrm{e}$ \\
BARI Tomato -10 & $34.3 \pm 2.2 \mathrm{a}$ & $32.5 \pm 2.3 \mathrm{a}$ & $1.8 \pm 0.1 \mathrm{df}$ & 5.2 & $78.7 \pm 1.3 \mathrm{~b}$ \\
BARI Tomato -11 & $14.8 \pm 1.1 \mathrm{~b}$ & $14.1 \pm 1.1 \mathrm{c}$ & $0.6 \pm 0.1 \mathrm{f}$ & 3.9 & $88.0 \pm 2.3 \mathrm{a}$ \\
BARI Tomato -12 & $31.8 \pm 2.7 \mathrm{a}$ & $27.6 \pm 2.6 \mathrm{ab}$ & $4.2 \pm 0.2 \mathrm{~b}$ & 13.2 & $70.7 \pm 1.3 \mathrm{~cd}$ \\
BARI Tomato -14 & $29.9 \pm 3.1 \mathrm{a}$ & $26.2 \pm 3.0 \mathrm{ab}$ & $3.7 \pm 0.3 \mathrm{bc}$ & 12.5 & $70.7 \pm 1.3 \mathrm{~cd}$ \\
BARI Tomato -15 & $34.2 \pm 3.4 \mathrm{a}$ & $32.8 \pm 3.6 \mathrm{a}$ & $1.6 \pm 0.1 \mathrm{ef}$ & 4.8 & $90.7 \pm 2.7 \mathrm{a}$ \\
\hline
\end{tabular}

Data expressed as mean \pm SE. Means within a column followed by same letter(s) are not significantly different by DMRT (p $\leq 0.05)$.

There were significant differences in total fruit yield $\left(\mathrm{F}_{9,20}=27.9, \mathrm{p}<0.001\right)$, healthy fruit yield $\left(\mathrm{F}_{9,20}=5.7, \mathrm{p}<0.01\right)$, infested fruit yield $\left(\mathrm{F}_{9,20}=12.2, \mathrm{p}<0.001\right)$ and seed germination $\left(\mathrm{F}_{9,20}=25.2, \mathrm{p}<0.001\right)$ of the screened varieties (Table 4). All the varieties except BARI Tomato-5 and BARI Tomato-11 showed statistically similar and higher total yield. The BARI Tomato-1, BARI Tomato-2, BARI Tomato4, BARI Tomato-7, BARI Tomato-10 and BARI Tomato-15 showed statistically similar and higher healthy fruit yield, and BARI Tomato-11revealed the lowest healthy fruit yield. The BARI Tomato-7 and BARI Tomato-11showed the highest and lowest infested fruit yield, respectively. The BARI Tomato-7 and BARI Tomato11 showed the highest and lowest yield reduction, respectively. The BARI Tomato15 revealed the highest performance in germination which was statistically identical with BARI Tomato-11. The BARI Tomato-7 depicted the lowest germination performance.

\section{DISCUSSION}

The varieties of plant species differ in their morphological characteristics such as leaf thickness, trichome density, pubescence, rind thickness and biochemical contents like percentage of starch, protein, amino acid, phenol etc. The variations in the host plant morphological characteristics and biochemical contents affect mating 
and oviposition behavior, foraging, feeding, growth and development, and population dynamics of herbivore insects (Amin et al., 2011; Amin et al., 2015). Rafiq et al. (2008) reported that plant characteristics are known to render the cultivars less suitable or unsuitable for the feeding, oviposition and development of insect pests. Goncalves-Alvin et al. (2004) reported that availability of the nutrients in the host plants improve their quality to attract the insects.

In the present study, the screened tomato varieties differed in their leaf thickness, trichome density, rind thickness and nitrogen content. Among the screened varieties, BARI Tomato-7 and BARI Tomato-12 possessed lowest trichome density and rind thickness, highest nitrogen content and comparatively lower leaf thickness, and the varieties were classified as resistant and moderately susceptible, respectively. Tomato plants possess glandular and nonglandular trichomes which are considered as the most important pest resistance factor (Gurr and McGrath, 2001; Simmons and Gurr, 2005). There are reports that the presence, density and distribution of the trichome depend on the tomato genotype, organs/tissue, age and environmental conditions (Wilkens et al., 1996; Gurr and McGrath, 2001; Kang et al., 2010).

In the present study, the tested varieties differed in their level of fruit infestation by fruit borer. That is why the varieties are classified as resistant, moderately resistant and moderately susceptible. Among the studied varieties, BARI Tomato-1, BARI Tomato-4, BARI Tomato-10, BARI Tomato-11 and BARI Tomato15 revealed significantly lower number of fruit borer larval abundance and exerted lower level of fruit infestation, and these varieties are classified as resistant. On the contrary, BARI Tomato-2, BARI Tomato-5, BARI Tomato-12 and BARI Tomato-14 revealed moderate number of fruit borer larval abundance and exerted moderate level of fruit infestation, and these varieties are classified as moderately resistant. The BARI Tomato-7 showed highest number of fruit borer larval population and depicted highest level of fruit infestation because of that the variety is classified as moderately susceptible. Kashyap and Verma (1986) recorded 42 to 55\% infestation of tomato fruits by fruit borer in susceptible varieties while it was 1.7 to $2.9 \%$ in resistant varieties. Singh and Narang (1990) observed $51.2 \%$ fruit infestation by $H$. armigera in Panjab, India. Singh et al. (2013) screened 13 varieties of tomato in Manipur, India and observed 8.47 to $8.5 \%, 10.2$ to $17.1 \%$ and 20.5 to $22.8 \%$ fruit infestation and classified the varieties as resistant, moderately resistant and moderately susceptible, respectively. Sajjad et al. (2011) evaluated thirty two tomato genotypes against fruit borer in Pakistan and categorized three genotypes as susceptible which had fruit infestation 36.4 to $37.7 \%$ and larval population 0.84 to $1.02 \%$ plant $^{-1}$, and three genotypes as resistant which had fruit infestation 12.30 to $13.96 \%$ and larval population 0.42 to $0.43 \%$ plant $^{-1}$.

Fruit length, diameter and weight are inherent characters of the varieties and these traits affect the yield. The present study showed that the screened tomato varieties differed in their fruit length, diameter, weight and yield. The varieties also 
showed variations in the reduction of fruit length, diameter, weight and yield which were caused due to the infestation of fruit borer. Among the tested varieties, BARI Tomato-7 showed comparatively higher level of fruit length and diameter reduction, and highest level of weight and yield reduction, as the variety exerted highest abundance of fruit borer larval abundance and infestation rate. The BARI Tomato-7 showed lowest percentage of germination due to the highest level of fruit infestation. The present findings indicated that the effect of fruit borer infestation on the yield and germination of the screened varieties was negative.

The present study showed that the BARI Tomato-1, BARI Tomato-4, BARI Tomato-10, BARI Tomato-11 and BARI Tomato-15 are classified as resistant against tomato fruit borer. It may be due to less flesh in fruits and rough surface of the plant. Mishra et al. (1988) reported that tomato genotypes with tight mesocarp and hard pulp of fruits are resistant. Selvanarayanan and Narayanasamy (2006) reported that trichome density in the foliage is the indication of resistant. The BARI Tomato-7 was found moderately susceptible, may be due to the reason of high nitrogen content, which accord with the findings of Minkenberg and Ottenheim (1990).

\section{CONCLUSION}

It can be concluded that out of the tested varieties BARI Tomato-1, BARI Tomato-4, BARI Tomato-10, BARI Tomato-11 and BARI Tomato-15 were found as resistant. The moderately susceptible variety was BARI Tomato-7. Further work is needed to characterize the mechanisms of resistance in tomato varieties against fruit borer.

\section{REFERENCES}

Alam, S. N., Rahman, A. K. M. Z. and Dutta, N. K. 2007. Annual report 2006-2007. Division of Entomology, BARI, Gazipur-1701. Pp.163

Amin, M. R., Roy, C. M., Rahman, M. M., Miah, G., Kwon, Y. J. and Suh, S. J. 2015. Foraging behavior of the cotton armyworm Spodoptera litura on some cotton varieties. Entomological Research, 45: 2861-293

Amin, M. R., Tithi, D. A. and Kwon, Y. J. 2011. Characteristics of three cotton varieties and their impact on feeding and growth of cotton armyworm. Entomological Research, 41: $151-156$

Bhatt, N. J. and Patel, R. K. 2001. Screening of chick pea cultivars for their resistance to gram pod borer, Helicoverpa armigera. Indian Journal of Entomology, 63: 277-280

Browne, B. L. B. and Raubenheimer, D. 2003. Ontogenetic changes in the rate of ingestion and estimates of food consumption in fourth and fifth instar Helicoverpa armigera caterpillars. Journal of Insect Physiology, 49: 63-71

Dhandapani, N. U., Shekhar, R. and Murugan, M. 2003. Bio-intensive pest management (BIPM) in major vegetable crops: an Indian perspective. Food, Agriculture and Environment, 1: 333-339 
Goncalves-Alvin, S. J., Collevatti, R. G. and Fernandes, G. W. 2004. Effects of genetic variability and habitat of Qualea parviflora (Vochysiacea) on herbivory by freefeeding and gall farming insects. Annals of Botany, 94: 259-268

Gurr, G. M. and McGrath, D. 2001. Effect of plant variety, plant age and photoperiod on glandular pubescence and host-plant resistance to potato moth (Phthorimaea operculella) in Lycopersicon spp. Annals of Applied Biology, 138: 221-230

Kang, J. H., Shi, F., Jones, A. D., Marks, M. D. and Howe, G. 2010. Distortion of trichome morphology by the hairless mutation of tomato affects leaf surface chemistry. Experimental Botany, 61: 1053-1064

Kashyap, R. K. and Verma, A. N. 1986. Screening of tomato genotypes for susceptibility to fruit borer, Heliothis armigera (Hubner). Indian Journal of Entomology, 48: 46-53

Matthews, M. 1999. Heliothine moths of Australia: A guide to pest bollworms and related noctuid groups. CSIRO Publishing, Collingwood, Victoria, Australia

Mehrvar, A. 2009. Persistence of different geographical isolates of Helicoverpa armigera nucleo polyhedron virus in two types of soils under different conditions. Journal of Biological Science, 9: 264

Minkenberg, O. P. J. M. and Ottenheim, J. G. W. 1990. Effects of leaf nitrogen content of tomato plants on preference and performance of a leaf mining fly. Oecologia, 83: 291298

Mishra, P. N., Singh, Y. V. and Nautiyal, M. C. 1988. Screening of brinjal varieties for resistance to shoot and fruit borer, Leucinodes orbonalis Guen. (Lepidoptera: Pyralidae). South Indian Horticulture, 36:182-88

Moser, S. E. and Obrycki, J. J. 2009. Non-target effects of neonicotinoid seed treatments; mortality of coccinellid larvae related to zoophytophagy. Biological Contents, 51: 487492

Rafiq, M., Ghaffar, A. and Arshad, M. 2008. Population dynamics of whitefly (Bemisia tabaci) on cultivated crop hosts and their role in regulating its carry-over to cotton. International Journal of Agricultural Biology, 9: 68-70

Sajjad, M., Ashfaq, M., Suhail, A. and Akhtar, S. 2011. Screening of tomato genotypes for resistance to tomato fruit borer (Helicoverpa armiger Hubner) in Pakistan. Pakistan Journal of Agricultural Sciences, 48: 59-62

Selvanarayanan, V. and Narayanasamy, P. 2006. Factors of resistance in tomato accessions against the fruit worm, Helicoverpa armigera (Hubner). Crop Protection, 25:10751079

Shelomi, M., Perkins, L. E., Cribb, B. W. and Zalucki, M. P. 2010. Effects of leaf surfaces on first-instar Helicoverpa armigera (Hübner) (Lepidoptera: Noctuidae) behavior. Australian Journal of Entomology, 49: 289-295

Simmons, A. T. and Gurr, G. M. 2005. Trichomes of Lycopersicon species and their hybrids: effects on pests and natural enemies. Agricultural Forest Entomology, 7: 265-276

Singh, D. and Narang, N. D. 1990. Control of tomato fruit borer, Helicoverpa armigera (Hubner) with synthetic pyrethroids. Indian Journal of Entomology, 52: 534-540 
Singh, M. S., Baruah, B. K. and Singh, K. I. 2013. Field screening of certain tomato varieties for their resistant reaction against Helicoverpa armigera (Hubner) in Manipur valley, India. The Clarion, 2: 56-58

Wilkens, R. T., Shea, G. O., Halbreich, S. and Stamp, N. E. 1996. Resource availability and the trichome defenses of tomato plants. Oecologia, 106:181-191 